\title{
Utilization of Spirulina (Arthrospira Platensis) in The Production of Functional Biscuits and its Effect on Product Quality
}

\author{
Hamid M. Ziena ${ }^{1}$, Mahmoud A. Rozan ${ }^{1}$ and Heba E. Ghozlan ${ }^{1}$
}

\begin{abstract}
The present study focused on results estimating impact of the addition $0, .5,1,1.5,2$ and $2.5 \%$ of Spirulina powder (SP) on the proximate chemical composition, energy (K.cal/100g), physical properties and sensory evaluation of the resultant biscuit samples. The data showed that Spirulina addition did not influence any deteriorative effect on the physical and sensorial characteristics with increasing in the nutritive value due to increment of Spirulina substitution level. In general, all treatments resulted in biscuits accepted organoleptically. The study recommends that spirulina powder could be essentially incorporated with biscuit formulation up to $2.5 \mathrm{gm} / 97.5$ gm wheat flour to improve its nutritional value without causing any quality attributes or sensorial defect.
\end{abstract}

Keywords: Biscuits, Spirulina, chemical composition, physical properties, sensory evaluation.

\section{INTRODUCTION}

The interest in food rich in protein, dietary fiber, and antioxidants, increased in recent decades and the importance of these food constituents has led to the development of a large market for nutritious, fiber and antioxidant-rich products and ingredients Tyagi et al., (2007). Biscuits are a popular food consumed in large quantities by the population due to their varied taste, shelf life and low cost. Therefore, efforts are being made to improve the nutritional value of biscuits and their functions by modifying their nutritional composition to be rich in protein, minerals and dietary fiber and improve the properties of probiotics for the final product, so we find a very large competition in the market to meet the desires of the consumer. Those looking for natural, healthy and functional products. Due to the increase in human awareness, it has led to their interest in the type of foods that are rich in antioxidants, which have a fundamental role in preventing various types of cancer and coronary heart disease, and phenolic compounds are considered one of the most anti-nutrients. Therefore, eating foods rich in phenolic substances increases the body's source of natural antioxidants (Sudha et al., 2007). Spirulina (Spirulina platensis) is blue - green algae that thrive in warm, alkaline fresh-water bodies. It is cultivated all around the world and is used as a human dietary supplement as well as whole food which are available in tablet, flake, and powder form. Spirulina provides a wide range of health benefits almost immediately upon ingestion.

It boosts the immune system, lowering cholesterol, heart health, diabetes treatment, wound healing, improving digestive health and as an antidote to depression and anxiety. Spirulina is also a natural detoxifier, oxygenating the blood, and helping cleanse the body of toxins and other impurities that may be causing illnesses or other health complications. Moreover, most research has focused on the health effects of spirulina as a dietary supplement for humans and therapeutic applications: an anti-cancer effect (Mao et al., 2005), a hypolipidemic effect (Narmadha et al., 2012). and a protective effect against diabetes and obesity (Anitha and Chandralekh, 2010). Presently, the use of foods that promote a state of wellbeing, better health, and reduction of the risk of diseases have become popular as the consumer is becoming more and more health conscious. So Spirulina consumption has increased due to its high protein content $(60-70 \%$ dry basis), high digestibility due to mucopolysaccharide cell wall, high concentration amino acids nucleic acids, and other bioactive compounds such as carotenoids, phycocyanins, chlorophyll, vitamins and fatty acids. Polyunsaturated like gamma-linolenic acids and linoleic acids (Jiménez et al., 2003, and Shimamatsu., 2004) . This study aimed to produce a functional biscuit contains spirulina without any deteriorative effect on the quality of the product.

\section{MATERIAL AND METHODS}

\section{Materials}

Wheat flour (Candy flour $72 \%$ extraction) was imported from the USA by International Co. for Trading, Ibn El. Khatab, Cairo, Egypt. The Spirulina platensis (blue-green algae) was cultivated, dried, and kindly provided by the National Research Centre, Cairo, Egypt. Powder sugar was obtained by Daqahlia Sugar Co., Belkas factory, Daqahlia, Egypt. Shortening was supplied by Integrated Oil Industries, Adabia, Suez, Egypt. Skimmed milk powder was imported from Ukraine. High farctoze corn serap HFCS was purchased from Corn Products Co., Cairo, Egypt. Ammonium bicarbonate $(\mathrm{NH} 4)_{2} \mathrm{CO}_{3}$ and sodium

DOI: 10.21608/ASEJAIQJSAE.2020.123819

${ }^{1}$ Faculty of Agriculture, Food and Dairy Science and

Technology Department, Damanhour University, 22516 - Egypt

Received October 21, 2020, Accepted November 15, 2020 
bicarbonate $\mathrm{NaHCO}_{3}$ were imported by Marvel Chemicals Co. from China. Lecithin (soya lecithin, food grade) was imported by Semiramis International Trade from E.E.C. Sodium chloride was obtained from El Max Salines Co., Alexandria, Egypt. Vanilla was imported by Garas Chemicals Co. from China.

\section{Processing methods}

Biscuit samples were prepared using the ingredients shown in Table 1.

The dough was prepared using the method adopted in Bisco Misr company, ElSeouf sector, Alexandria, Egypt. The dough was mixed in Werner and Pfleiderer Stuttgart Fed. Rep. Germany. Type U K 166B. At first, the sugar, shortening, HFCS, $80 \%$ of water amount were mixed for the cream formation. All these ingredients were mixed for one min at $40 \mathrm{rpm}$ then the speed was increased to $80 \mathrm{rpm}$ for two min, after that the wheat flour and sodium bicarbonate were added and mixed for two min at $40 \mathrm{rpm}$, then ammonium bicarbonate, and vanillin were added. The mix was stirred in the mixer at $40 \mathrm{rpm}$ approximately for two min or until the dough becomes homogenous. The dough was let to rest for two hours in stainless steel dough cart $(90 \mathrm{~cm} \times 120 \mathrm{~cm} \times 90 \mathrm{~cm})$ in a warm place until it rises. The dough was then dropped into the hopper of the formation machine (Vuurslage, type rotary molder 2006). This machine consists of one pairs of stainless steel drums mission to press the form of biscuit (circular shape) on a cotton conveyor belt which transfer to the oven steel conveyor. Baking of biscuits was carried out in the three stages oven (Laurance Banonnd, Paris, France) at 212, 235, and $200{ }^{\circ} \mathrm{C}$; respectively for eight (8) min. next, the biscuits are left to cool down at room temperature, packed in pouches, and sealed.

\section{The chemical analysis methods:}

Chemical composition of biscuit samples was carried out using the AACC Approved Methods (AACC, 2000). Approved methods of AACC were as follow: Moisture content (method 44- 16), crude protein content (method 46-13) crude fat content (method 3010), ash content (method 08-01), crude fiber content (method 32-10), while carbohydrate content was obtained by difference. The energy value was calculated based on the centesimal composition, using Atwater conversion factors (Merril et al., 1973). The extraction of antioxidant compounds was conducted with an ethanolic aqueous solution of $80 \% \quad(\mathrm{v} / \mathrm{v})$. The quantification of total phenolic compounds $(T P C)$ was realized by Folin-Ciocalteu method, as described by Swain and Hillis, (1959), the absorbance is measured at 760 nm (spectrophotometer 700 Plus, Femto, São Paulo, Brazil). For quantification, a standard curve was prepared with gallic acid and the results were expressed as grams of gallic acid equivalent per kilogram of the sample. The total flavonoid content (TFC) was estimated spectrophotometrically by the aluminium chloride method based on the formation of complex flavonoid-aluminium. One milliliter of the sample was mixed with $1 \mathrm{~mL}$ of $\mathrm{AlCl}_{3}$ methanolic solution $(2 \%$, $\mathrm{w} / \mathrm{v})$. After incubation at room temperature for $15 \mathrm{~min}$, the absorbance was read at $430 \mathrm{~nm}$. The amount of TFC was estimated from the standard calibration curve of 10100 mg ml-1quercetin Hoseini et al., (2013).

Table 1. The ingredients of different biscuit samples and their proportions

\begin{tabular}{|c|c|c|c|c|c|c|c|c|c|c|c|c|}
\hline & $\begin{array}{c}\text { Control } \\
(\mathbf{K g})\end{array}$ & $\%$ & $\begin{array}{c}\mathbf{0 . 5 \%} \\
\text { Spirulina } \\
(\mathrm{Kg})\end{array}$ & $\%$ & $\begin{array}{c}1.0 \% \\
\text { Spirulina } \\
(\mathrm{Kg})\end{array}$ & $\%$ & $\begin{array}{c}1.5 \% \\
\text { Spirulina } \\
(\mathrm{Kg})\end{array}$ & $\%$ & $\begin{array}{c}2.0 \% \\
\text { Spirulina } \\
\text { (Kg) }\end{array}$ & $\%$ & $\begin{array}{c}2.5 \% \\
\text { Spirulina } \\
\text { (Kg) }\end{array}$ & $\%$ \\
\hline $\begin{array}{l}\text { Wheat } \\
\text { flour }\end{array}$ & 2.975 & 100 & 2.960 & 99.5 & 2.945 & 99.0 & 2.930 & 98.5 & 2.915 & 98.0 & 2.900 & 97.5 \\
\hline Spirulina & 0.000 & 0.0 & 0.015 & 0.5 & 0.030 & 1.0 & 0.045 & 1.5 & 0.060 & 2.0 & 0.075 & 2.5 \\
\hline Sugar & 0.684 & 23 & 0.684 & 23 & 0.684 & 23 & 0.684 & 23 & 0.684 & 23 & 0.684 & 23 \\
\hline Shortening & 0.620 & 20.8 & 0.620 & 20.8 & 0.620 & 20.8 & 0.620 & 20.8 & 0.620 & 20.8 & 0.620 & 20.8 \\
\hline HFCS & 0.260 & 8.7 & 0.260 & 8.7 & 0.260 & 8.7 & 0.260 & 8.7 & 0.260 & 8.7 & 0.260 & 8.7 \\
\hline $\mathrm{NaHCO}_{3}$ & 0.037 & 1.2 & 0.037 & 1.2 & 0.037 & 1.2 & 0.037 & 1.2 & 0.037 & 1.2 & 0.037 & 1.2 \\
\hline$(\mathrm{NH} 4)_{2} \mathrm{CO}_{3}$ & 0.062 & 2.0 & 0.062 & 2.0 & 0.062 & 2.0 & 0.062 & 2.0 & 0.062 & 2.0 & 0.062 & 2.0 \\
\hline Lecithin & 0.006 & 0.20 & 0.006 & 0.20 & 0.006 & 0.20 & 0.006 & 0.20 & 0.006 & 0.20 & 0.006 & 0.20 \\
\hline Vanilla & 0.003 & 0.10 & 0.003 & 0.10 & 0.003 & 0.10 & 0.003 & 0.10 & 0.003 & 0.10 & 0.003 & 0.10 \\
\hline Salt & 0.006 & 0.20 & 0.006 & 0.20 & 0.006 & 0.20 & 0.006 & 0.20 & 0.006 & 0.20 & 0.006 & 0.20 \\
\hline Water & 0.347 & 11.6 & 0.347 & 11.6 & 0.347 & 11.6 & 0.347 & 11.6 & 0.347 & 11.6 & 0.347 & 11.6 \\
\hline
\end{tabular}


The scavenging activity of DPPH $\bullet$ radicals (2,2diphenyl-1-picrylhydrazyl; Sigma- Aldrich Chemical, St Louis, Missouri, USA) was determined according to Brand-Williams et al. (1995). The ferric reduction power (FRAP) of the extract was assessed following the methodology described by Benzie and Strain (1996). The antioxidant capability of the extracts with ABTS •+ free radical (2,2-azino-bis-3-ethylbenzothiazoline-6sulfonic acid; Sigma-Aldrich Chemical) was carried out according to Thaipong et al. (2009).

\section{Physical properties determination methods:}

Diameter (D) was measured by laying six biscuits edge-to-edge with the help of a scale. Average values of these biscuits were recorded in millimeter. Thickness (T) of biscuits was measured by stacking six biscuits on top of one another and taking the average of six biscuits in millimeter. The spread ratio was calculated by dividing the mean of (D) by thickness (T). Density of biscuits was calculated by dividing the mean weight of six biscuits by the apparent volume $\pi \mathrm{r}^{2 *}(\mathrm{~T})$ and expressed as g per cc. (Ameur, et al, 2007). The surface color of the resultant biscuit samples was measured with a Hunter lab Color quest colorimeter (Reston, VA, USA) calibrated with a white and black tile. The device was set to an illuminant condition D65 (medium daylight) and a 10_ (field of view) standard observer. Color of samples placed in a clear Petri dish was measured at least in five-fold. The results were expressed as CIE $1967 \mathrm{~L}^{*}, \mathrm{a}^{*}, \mathrm{~b}^{*}$-values. $\mathrm{L}^{*}$ is a measure of the brightness from black (0) to white (100), while $a^{*}$ describes the red, green color $\left(a^{*}>0\right.$ indicates redness, $a^{*}<0$ indicates greenness), and $b^{*}$ describes yellow, blue color $\left(b^{*}>0\right.$ indicates yellowness, $b^{*}<0$ indicates blueness). The determination of biscuit hardness was made by Brookfield CT3 Texture Analyzer (Brookfield Engineering Laboratories, Middleboro, Massachusetts, USA). Each biscuit sample was placed horizontally in a platform and cut in half, using a knife-shaped probe TA-SBA (texture analyzer shear blade accessory), with pretest speed of $2.0 \mathrm{~mm} . \mathrm{s}-$ 1 , test speed of $5.0 \mathrm{~mm} . \mathrm{s}-1$, trigger force of $0.07 \mathrm{~N}$ and distance of $8.0 \mathrm{~mm}$, thus determining the rupture force (hardness). Ten determinations were made for each formulation in samples randomly selected and the results were expressed in newtons.

\section{Sensory Evaluation:}

Sensory attributes such as color, flavor, texture and overall acceptability of all biscuit samples were evaluated using 10 of well-trained judges by the method recommended by Hooda and Jood (2005) using a hedonic scale ranging from 10 (like extremely) to 1 (dislike extremely), for each organoleptic characteristic.

\section{Statistical Analysis:}

All the experiments were performed in triplicate and variations in the values expressed as standard deviations. A one-way ANOVA was performed to determine significant differences $(\mathrm{P}<0.05)$ by using Duncan's multiple range test using the software Statistical version 7.0 (StatSoft, Tulsa, Oklahoma, USA), including the analysis of principal components.

\section{RESULTS AND DISCUSSION}

\section{Chemical analysis of spirulina:}

The chemical analysis of Arthrospira platensis is shown in Table 2. Moisture, crude protein ( $\mathrm{N} x$ 6.25), crude fat, ash, crude fiber, and N- Free extract were 4.81 $\pm 0.12,63.26 \pm 0.74,2.67 \pm 0.14,2.34 \pm 0.09$ and 21.54 $\pm 0.41 \%$, respectively.

Total phenolics and total flavonoids were $1288 \pm 23$ and $865 \pm 15 \mathrm{mg} / 100 \mathrm{~g}$, respectively. DPPH, ABTS and FRAP were $77.8 \pm 6.8,4.32 \pm 0.27$ and $42.9 \pm 3.8 \mathrm{mmol}$ $/ \mathrm{Kg}$, respectively. These values make spirulina a good raw material for healthy food.

Table 2. Chemical composition, some phytochemicals and antioxidant activity of spirulina

\begin{tabular}{cc}
\hline Constituent/Character & Value (mean \pm SD) \\
\hline Moisture (\%) & $4.81 \pm 0.12$ \\
Crude protein (N x 6.25, \%) & $63.26 \pm 0.74$ \\
Crude fat (\%) & $2.67 \pm 0.14$ \\
Ash (\%) & $2.34 \pm 0.09$ \\
Crude fiber (\%) & $5.38 \pm 0.24$ \\
N- Free extract (\%) (by difference) & $21.54 \pm 0.41$ \\
Total phenolics (mg / 100g) & $1288 \pm 23$ \\
Total flavonoids (mg / 100 g) & $865 \pm 15$ \\
DPPH (mmol / Kg) & $77.8 \pm 6.8$ \\
ABTS (mmol / Kg) & $4.32 \pm 0.27$ \\
FRAP (mmol / Kg) & $42.9 \pm 3.8$ \\
\hline
\end{tabular}




\section{The chemical analysis of biscuit samples:}

The data presented in Table (3) show the chemical composition of different biscuit samples made with different amounts of spirulina powder. It was clear that the moisture content in the samples did not differ significantly, it arranged between $3.24 \%$ and $3.33 \%$. Meanwhile. The crude protein, ash, crude ether extract and crude fiber contents were significantly higher in all biscuit samples in which the spirulina algae was replaced compared to the B10 (control sample). The value of crude protein increased from 6.88 to $8.01 \%$ while ash ranged between $0.63 \%$ and $0.88 \%$ and crude ether extract ranged between $12.89 \%$ and $13.38 \%$ as well, crude fiber varied from $0.71 \%$ to $0.96 \%$. It was clear that the addition of dried spirulina on biscuits product resulted in decreasing in the N-Free Extract from $72.46 \%$ to $69.55 \%$ and increasing in the energy from 461.81 to 464.33 ( $\mathrm{kcal} / 100 \mathrm{~g})$. This result agrees with Onacik-Gur et al., (2018) and Batista et al., (2017).

\section{physical properties:}

Physical properties values of the different biscuit samples are shown in Table (4). The addition of dried spirulina on the biscuit product did not significantly affect the most physical properties studied except the density of biscuits compared to B10 (control biscuits), but the effect was very slight where the weight, diameter, thickness. On the other hand, spread ratio, and volume of biscuit decreased compared to B10, while the density of biscuit increased significantly on increasing the level of spirulina addition. Other researchers found that the addition of fiber may have such an impact on a spread Gupta et al.,(2011).

Table 3. Proximate chemical composition of biscuit samples *

\begin{tabular}{|c|c|c|c|c|c|c|c|}
\hline Treatment $* *$ & $\begin{array}{c}\text { Moisture } \\
(\%)\end{array}$ & $\begin{array}{c}\text { Crude } \\
\text { protein } \\
(\mathbf{N} \times 5.7)\end{array}$ & $\begin{array}{c}\text { Crude } \\
\text { ether } \\
\text { extract } \\
(\%)\end{array}$ & $\begin{array}{l}\text { Ash } \\
(\%)\end{array}$ & $\begin{array}{c}\text { Crude fiber } \\
(\%)\end{array}$ & $\begin{array}{c}\text { N-Free } \\
\text { Extract } \\
(\%)\end{array}$ & $\begin{array}{c}\text { Energy } \\
\text { (kcal/100g) }\end{array}$ \\
\hline B10 & $3.28 \pm 0.05$ & $\begin{array}{l}6.88 \pm \\
0.18 f+\end{array}$ & $\begin{array}{c}12.98 \pm \\
0.31 \mathrm{c}\end{array}$ & $\begin{array}{c}0.63 \pm \\
0.03 \mathrm{c}\end{array}$ & $0.71 \pm 0.02 \mathrm{~d}$ & 75.52 & 446.42 \\
\hline B11 & $3.37 \pm 0.04$ & $\begin{array}{l}7.05 \pm \\
0.16 \mathrm{e}\end{array}$ & $\begin{array}{c}13.12 \pm \\
0.37 \mathrm{bc}\end{array}$ & $\begin{array}{c}0.68 \pm \\
0.03 \mathrm{c}\end{array}$ & $0.76 \pm 0.02 \mathrm{~cd}$ & 75.02 & 446.36 \\
\hline B12 & $3.30 \pm 0.07$ & $\begin{array}{l}7.31 \pm \\
0.20 \mathrm{~d}\end{array}$ & $\begin{array}{c}13.20 \pm \\
0.28 \mathrm{bc}\end{array}$ & $\begin{array}{c}0.73 \pm \\
0.01 \mathrm{bc}\end{array}$ & $0.84 \pm 0.02 b c$ & 74.62 & 446.52 \\
\hline B13 & $3.24 \pm 0.04$ & $\begin{array}{l}7.59 \pm \\
0.18 \mathrm{c}\end{array}$ & $\begin{array}{l}13.26 \pm \\
0.27 \mathrm{abc}\end{array}$ & $\begin{array}{l}0.80 \pm \\
0.03 \mathrm{ab}\end{array}$ & $0.90 \pm 0.01 \mathrm{ab}$ & 74.21 & 446.54 \\
\hline B14 & $3.31 \pm 0.04$ & $\begin{array}{l}7.86 \pm \\
0.18 \mathrm{~b}\end{array}$ & $\begin{array}{c}13.31 \pm \\
0.36 \mathrm{ab}\end{array}$ & $\begin{array}{c}0.85 \pm \\
0.02 \mathrm{a}\end{array}$ & $0.93 \pm 0.02 \mathrm{ab}$ & 73.74 & 446.16 \\
\hline B15 & $3.33 \pm 0.06$ & $\begin{array}{c}8.01 \pm \\
0.16 \mathrm{a} \\
\end{array}$ & $\begin{array}{c}13.38 \pm \\
0.35 \mathrm{a} \\
\end{array}$ & $\begin{array}{c}0.88 \pm \\
0.02 \mathrm{a} \\
\end{array}$ & $0.96 \pm 0.03 a$ & 73.44 & 446.22 \\
\hline
\end{tabular}

*B10: Control biscuit; B11, B12, B13, B14 and B15 are biscuits contained 0.5, 1.0, 1.5, 2.0 and 2.5\% dried spirulina, respectively. ** Mean of triplicates \pm SD (D.W.B.)

+ Means in a column not sharing the same superscript are significantly different at $\mathrm{p} \leq 0.05$.

Table 4 . Physical characteristics of biscuit samples *

\begin{tabular}{ccccccc}
\hline Sample $^{* * *}$ & $\begin{array}{c}\text { Weight of } \\
\text { biscuit }(\mathbf{g})\end{array}$ & $\begin{array}{c}\text { Diameter of } \\
\text { biscuit }(\mathbf{c m})\end{array}$ & $\begin{array}{c}\text { Thickness of } \\
\text { biscuit }(\mathbf{m m})\end{array}$ & Spread ratio & $\begin{array}{c}\text { Volume of } \\
\text { biscuit }\left(\mathbf{c m}^{3}\right)\end{array}$ & $\begin{array}{l}\text { Density of biscuit } \\
\left(\mathbf{g} / \mathbf{c m}^{3}\right)\end{array}$ \\
\hline B10 & $11.422 \pm 0.201^{\mathrm{a}}$ & $6.32 \pm 0.09^{\mathrm{a}}$ & $6.17 \pm 0.13^{\mathrm{a}}$ & $10.24 \pm 0.24^{\mathrm{ab}}$ & $19.34 \pm 0.37^{\mathrm{a}}$ & $0.5905 \pm 0.0101^{\mathrm{b}}$ \\
$\mathrm{B} 11$ & $11.349 \pm 0.128^{\mathrm{a}}$ & $6.30 \pm 0.06^{\mathrm{a}}$ & $6.15 \pm 0.09^{\mathrm{a}}$ & $10.24 \pm 0.19^{\mathrm{ab}}$ & $19.16 \pm 0.32^{\mathrm{ab}}$ & $0.5923 \pm 0.0113^{\mathrm{ab}}$ \\
$\mathrm{B} 12$ & $11.365 \pm 0.167^{\mathrm{a}}$ & $6.31 \pm 0.10^{\mathrm{a}}$ & $6.13 \pm 0.12^{\mathrm{a}}$ & $10.29 \pm 0.28^{\mathrm{a}}$ & $19.16 \pm 0.41^{\mathrm{ab}}$ & $0.5931 \pm 0.0088^{\mathrm{ab}}$ \\
$\mathrm{B} 13$ & $11.410 \pm 0.210^{\mathrm{a}}$ & $6.32 \pm 0.09^{\mathrm{a}}$ & $6.15 \pm 0.14^{\mathrm{a}}$ & $10.28 \pm 0.31^{\mathrm{a}}$ & $19.28 \pm 0.39^{\mathrm{a}}$ & $0.5918 \pm 0.0107^{\mathrm{b}}$ \\
$\mathrm{B} 14$ & $11.385 \pm 0.155^{\mathrm{a}}$ & $6.28 \pm 0.11^{\mathrm{a}}$ & $6.18 \pm 0.11^{\mathrm{a}}$ & $10.16 \pm 0.24^{\mathrm{c}}$ & $19.13 \pm 0.44^{\mathrm{b}}$ & $0.5951 \pm 0.0110^{\mathrm{a}}$ \\
$\mathrm{B} 15$ & $11.374 \pm 0.173^{\mathrm{a}}$ & $6.29 \pm 0.08^{\mathrm{a}}$ & $6.16 \pm 0.10^{\mathrm{a}}$ & $10.20 \pm 0.30^{\mathrm{bc}}$ & $19.13 \pm 0.52^{\mathrm{b}}$ & $0.5945 \pm 0.0938^{\mathrm{a}}$ \\
\hline
\end{tabular}

* Mean of ten replicates \pm SD, Means in a column not sharing the same superscript are significantly different at $\mathrm{p} \leq 0.05$.

**B10: Control biscuit; B11, B12, B13, B14 and B15 are biscuits contained 0.5, 1.0, 1.5, 2.0 and 2.5\% dried spirulina, respectively. 
The data presented in Table (5) show the texture (Hardness) of different biscuit samples. It was clear that hardness of biscuits increased as spirulina is increased that the ratio of changing ranged between $0.0 \%$ in the control to $15.6 \%$ in (T6). Our result agrees with Abd Elbaky et al.,(2015).

Table 5. Texture (Hardness) of biscuit samples *

\begin{tabular}{ccc}
\hline $\begin{array}{c}\text { Treatment } \\
\text { (\%Spirulina) }\end{array}$ & Biscuit(Newteon)*** & $\begin{array}{l}\text { Biscuit } \\
\text { (\% change) }\end{array}$ \\
\hline T1 $(0.0)$ & $2325 \pm 121^{\mathrm{d}}$ & 0.0 \\
T2 $(0.5)$ & $2396 \pm 154^{\mathrm{cd}}$ & +3.1 \\
T3 $(1.0)$ & $2435 \pm 101^{\mathrm{bc}}$ & +4.1 \\
T4 $(1.5)$ & $2517 \pm 134^{\mathrm{b}}$ & +8.2 \\
T5 $(2.0)$ & $2606 \pm 095^{\mathrm{a}}$ & +12.1 \\
T6 $(2.5)$ & $2688 \pm 159^{\mathrm{a}}$ & +15.6 \\
\hline
\end{tabular}

* Mean of triplicates \pm SD.

** Means in a column not sharing the same superscript are significantly different at $\mathrm{p} \leq 0.05$.

\section{Color properties:}

Table (6) shows the effect of dried spirulina addition on the color of the biscuit surface. All biscuits contained spirulina gave significantly lower $\mathrm{L}^{*}$ readings, indicating a dark golden color and heavier in color, values ranging from 64.64 to 51.89 . In general, L* values decreased significantly with increased dried spirulina in biscuits. As well as the values of a,b,c decreased significantly with increasing dried spirulina in biscuits. The value of (a) ranged between 14.18 and 10.90 , the value of (b) 38.94 to 29.77 , the value of (c) varied from 41.44 to 31.70 and the Total color intense decreased significantly with increased dried spirulina in biscuits that ranged between 76.78 and 60.80. This result agrees with Gouveia et al., (2008) and Minh (2014).

\section{Sensory evaluation}

Table (7) shows the sensory evaluation of different biscuits. Results showed that there was no significant difference before and after adding of spirulina that results were in appearance, color, flavor and texture increased slightly except color where the color is darker than the color of the control sample (B10) that was 8.70 while (B15) had a score 6.95. However, Overall acceptability ranged between 8.65in (B10) and 6.83in (B15). Our result agrees with Kim et al., (2012).

Table 6. Hunter lab color data for biscuit samples

\begin{tabular}{cccccccc}
\hline Treatment $^{+}$ & $\mathbf{L}^{*}$ & $\mathbf{a}^{*}$ & $\mathbf{b}^{*}$ & $\mathbf{C}^{++}$ & $\Delta \mathbf{a}^{*-}$ & $\Delta \mathbf{b}^{*--}$ & $\mathbf{T C I}^{+++}(\Delta \mathbf{E})$ \\
\hline B10 & 64.64 & 14.18 & 38.94 & 41.44 & 0.0 & 0.0 & 76.78 \\
B11 & 62.05 & 13.86 & 36.67 & 39.20 & -0.32 & -2.27 & 73.40 \\
B12 & 60.13 & 13.22 & 34.56 & 37.00 & -0.96 & -4.38 & 70.60 \\
B13 & 57.76 & 12.57 & 32.83 & 35.15 & -1.61 & -6.11 & 67.62 \\
B14 & 55.40 & 11.71 & 31.92 & 34.00 & -2.47 & -7.02 & 65.00 \\
B15 & 51.89 & 10.90 & 29.77 & 31.70 & -3.28 & -9.17 & 60.80 \\
\hline
\end{tabular}

${ }^{+}$B10: Control biscuit; B11, B12, B13, B14 and B15 are biscuits contained 0.5, 1.0, 1.5, 2.0 and 2.5\% dried spirulina, respectively. $\mathrm{C}^{++}$Chroma (purity) $=\left(\mathrm{a}^{* 2}+\mathrm{b}^{* 2}\right)^{1 / 2}$

TCI $(\Delta \mathrm{E})^{+++}$: Total color intensity $=\left(\mathrm{a}^{* 2}+\mathrm{b}^{* 2}+\mathrm{L}^{* 2}\right)^{1 / 2}$

$\Delta \mathrm{a}^{*-}=\mathrm{a}^{*}$ (sample) - $\mathrm{a}^{*}$ (control), $\Delta \mathrm{b}^{*-}=\mathrm{b}^{*}$ (sample) $-\mathrm{b}^{*}$ (control)

Table 7. Sensory evaluation of biscuit samples

\begin{tabular}{cccccc}
\hline Sample* $^{*}$ Appearance+ & Color & Flavor & Texture & $\begin{array}{c}\text { Overall } \\
\text { acceptability }\end{array}$ \\
\hline B10 & $8.66 \pm 0.39^{\mathrm{a}}$ & $8.70 \pm 0.28^{\mathrm{a}}$ & $8.46 \pm 0.37^{\mathrm{a}}$ & $8.53 \pm 0.33^{\mathrm{a}}$ & $8.65 \pm 0.33^{\mathrm{a}}$ \\
B11 & $8.42 \pm 0.37^{\mathrm{ab}}$ & $8.37 \pm 0.30^{\mathrm{ab}}$ & $8.39 \pm 0.40^{\mathrm{a}}$ & $8.60 \pm 0.28^{\mathrm{a}}$ & $8.46 \pm 0.42^{\mathrm{a}}$ \\
B12 & $8.26 \pm 0.40^{\mathrm{bc}}$ & $8.14 \pm 0.35^{\mathrm{bc}}$ & $8.20 \pm 0.35^{\mathrm{ab}}$ & $8.70 \pm 0.33^{\mathrm{a}}$ & $8.34 \pm 0.30^{\mathrm{a}}$ \\
B13 & $8.10 \pm 0.30^{\mathrm{cd}}$ & $7.80 \pm 0.37^{\mathrm{cd}}$ & $8.24 \pm 0.29^{\mathrm{ab}}$ & $8.51 \pm 0.42^{\mathrm{a}}$ & $7.99 \pm 0.38^{\mathrm{b}}$ \\
B14 & $7.95 \pm 0.31^{\mathrm{cd}}$ & $7.45 \pm 0.28^{\mathrm{de}}$ & $8.18 \pm 0.41^{\mathrm{ab}}$ & $8.62 \pm 0.35^{\mathrm{a}}$ & $7.52 \pm 0.27^{\mathrm{b}}$ \\
B15 & $7.57 \pm 0.36^{\mathrm{d}}$ & $6.98 \pm 0.32^{\mathrm{e}}$ & $7.98 \pm 0.36^{\mathrm{b}}$ & $8.44 \pm 0.28^{\mathrm{a}}$ & $6.83 \pm 0.32^{\mathrm{c}}$ \\
\hline
\end{tabular}

$* \overline{\mathrm{B} 10:}$ Control biscuit; B11, B12, B13, B14 and B15 are biscuits contained 0.5, 1.0, 1.5, 2.0 and 2.5\% dried spirulina, respectively.

** Mean of 10 replicates \pm SD

+ Means in a pole don't share same superscript are significantly different at $\mathrm{p} \leq 0.05$. 


\section{CONCLUSIONS}

As a conclusion, Spirulina powder could be essentially incorporated with biscuit formulation up to $2.5 \mathrm{gm} / 97$. $5 \mathrm{gm}$ wheat flour to improve its nutritional value without causing any quality attributes or sensorial defect.

\section{REFERENCES}

AACC. 2000. AACC Approved Methods. The American Association of Cereal Chemists. $10^{\text {th }}$ Edition.

Abd El- baky, H.H, G.S. El-Baroty and E.A. Ibrahim. 2015. Functional characters' evaluation of biscuits sublimated with pure phycocyanin isolated from Spirulina and Spirulina biomass. Nutr Hosp. 32(1):231-241.

Ameur, L.A., O.Mathieu, V.Lalanna, G.Trystram. and I. Birlouez-Aragon. 2007. Comparison of the effects of sucrose and hexose on furfural formation and browning in cookies baked at different temperatures. Food Chemistry. 101:1407-1416.

Anitha, L. and K. Chandralekha. 2010. Effect of Supplementation of Spirulina on Blood Glucose, Glycosylated Hemoglobin and Lipid Profile of Male NonInsulin Dependent Diabetics. Asianj. Exp. Biol. SCI. 1 (1):36-46.

Batista, A.P., A.Niccolai, P.Fradinho, S.Fragoso, I.Bursic, L.Rodolfi, N. Biondi. and M.R. Tredici. 2017. Microalgae biomass as an alternative ingredient in cookies: sensory, physical and chemical properties, antioxidant activity and in vitro digestibility. Algal Res. 26: 161-71.

Benzie, I. F. F. and J. J.Strain. 1996.: The ferric reducing ability of plasma (FRAP) as a measure of "antioxidant power": The FRAP assay. Analytical Biochemistry. 239: 70-76.

Brand-Williams, W., M. E. Cuvelier and C. Berset.1995. Use of a free radical method to evaluate antioxidant activity. Lebensmittel-Wissenschaft Technologie. 28: 25-30.

Gouveia, L., C.Coutinho, E.Mendonça, A.P.Batista, I.Sousa, N.M.Bandarra and A.Raymundo. 2008. Functional biscuits with PUFA- $\omega 3$ from Isochrysis galbana. J. Sci. Food Agr. 88:891-896.

Gupta, M., A.S. Bawa and N.Abu-Ghannam. 2011. Effect of barley flour and freeze-thaw cycles on textural nutritional and functional properties of cookies. FBP. 89:520-527.

Hooda, J. and S. Jood. 2005. Organoleptic and nutritional evaluation of wheat biscuits supplemented with untreated and treated fenugreek flour. Food Oxyradicals and DNA damage. Carcinogenesis. 21:361-37.
Hoseini, S.M., K.Khosravi-Darani and M.R. Mozafari. 2013. Nutritional and medical applications of Spirulina microalgae. Mini-Reviews in Medicinal Chemistry. 13: 1231-1237.

Jiménez, C., B.R.Cossío, D.Labella and F.X. Niell. 2003. The feasibility of industrial production of Spirulina (Arthrospira) in Southern Spain. Aquaculture. 217(1-4): 179-90.

Kendall, C. W. C., A.Esfahani and D. J. A. Jenkins. 2010. The link between dietary fibre and human health. Food Hydrocolloids. 24:42-48.

Kim, E. H-J., V.K.Corrigan, A.J.Wilson, I.R.Waters, D.I. Hedderley and M.P. Morgenstern. 2012. Fundamental fracture properties associated with sensory hardness of brittle solid foods. J. Texture Studies. 43: 49-62.

Mao, T., J.Van and M. Gershwin. 2005. Effects of a Spirulinabased dietary supplement on cytokine production from allergic rhinitis patients. J. of Medicinal Food. 8(1):27-3.

Minh, N.P. 2014. Effect of Saccharomyces cerevisiae, Spirulina and preservative supplementation to sweet bread quality in bakery International $\mathbf{J}$. of Multidisciplinary Research and Development. 1(4): 36-44.

Merril, A. L. and B. K. Watt. 1973. Energy value of foods: basis and derivation. Washington: Agricultural Research Service. 105 pp. ISBN 1234190427.

Narmadha, T., V.Sivakami and M. Ravikumar. 2012. Mukeshkumar, D., Effect of Spirulina on lipid profile of hyperlipidemics. World J. of Science and Technology. 2:19-22.

Onacik-Gu, S., A. Zbikowska and B.Majewska. 2018. Effect of spirulina (Spirulina platensis) addition on textural and quality properties of cookies. Ital J. Food Sci. vol. 30

Shimamatsu, H. 2004. Mass production of Spirulina, an edible microalga. Hydrobiologia. 512: 39-44.

Sudha, M. L., A. K.Srivastava, R.Vetrimani and K. Leelavathi. 2007. Fat replacement in soft dough biscuits: its implications on dough rheology and biscuit quality. J. of Food Engineering. 80:922-930.

Swain, T. and W. E.Hillis. 1959. The phenolic constituents of Prunus domestica - the quantitative analysis of phenolic constituents. J. of Sci. Food Agriculture. 10: 63-68.

Thaipong, K., U.Boonprakob, K. Crosby, L. CisnerosZevallos and D. H.Byrne. 2009. Comparison of ABTS, DPPH, FRAP and ORAC assays for estimating antioxidant activity from guava fruit extracts. J. of Food Composition Analysis. 19: 669-675.

Tyagi, S. K., M. R. Manikantan, S.Harinder Oberoi and Kaur. 2007. Effect of mustard flour incorporation on nutritional, textural and organoleptic characteristics of biscuits. J. of Food Engineering. 80:1043-1050. 
Hamid M. Ziena et al.-: Utilization of Spirulina (Arthrospira Platensis) in The Production of Functional Biscuits and .......

453

الملخص العربي

استخدام السبيرولينا (Arthrospira platensis) في إنتاج البسكويت الوظيفي وتأثيره على جودة المنتج حامد مرسي زينة ومحمود عبد الجليل روزن وهبة السيد غزلان

بالبييرولينا. وبشكل عام، أدت جميع المعاملات إلى قبول تصني

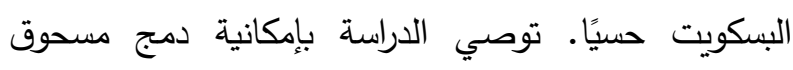

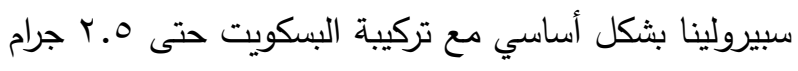

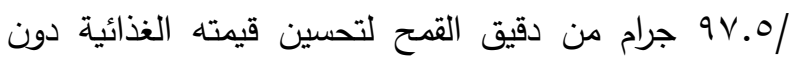
التسبب في أي عيب في سمات الجودة أو التقبل الحسي لفئ دون

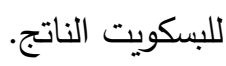

كان الهذف من هذا البحث هو دراسة تأثير إضافة .،

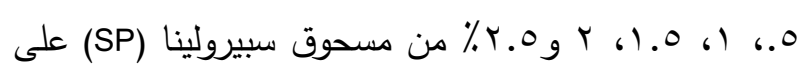

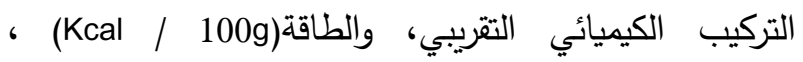

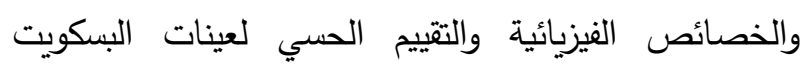
الناتج. أوضحت البيانات أن إضافة مسحوق السبيرولينا لم المئل

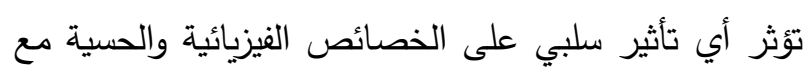

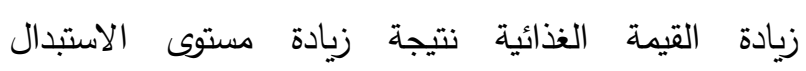

